Proc. Estonian Acad. Sci. Biol. Ecol., 2003, 52, 3, 218-235

\title{
Effects of eutrophication and invasion of Dreissena polymorpha in the coastal zone of the eastern Gulf of Finland
}

\author{
Sergey M. Golubkov ${ }^{a^{*}}$, Saara Bäck ${ }^{\mathrm{b}}$, Vera N. Nikulina ${ }^{\mathrm{a}}$, Marina I. Orlova ${ }^{\mathrm{a}}$, \\ Lydia E. Anokhina ${ }^{a}$, and Ludmila P. Umnova ${ }^{a}$ \\ a Zoological Institute of the Russian Academy of Sciences, 199034 St. Petersburg, Russia \\ b Finnish Environment Institute, P.O.Box 140, FIN-00251 Helsinki, Finland; Saara.Back@vyh.fi
}

Received 9 January 2003, in revised form 24 June 2003

\begin{abstract}
Ecosystem studies in the littoral zone of the Neva estuary have shown that eutrophication is a serious environmental problem for the coastal zone of the eastern part of the Gulf of Finland. It brings about an intensive development of filamentous algae Cladophora glomerata and periodical blue-green blooms. Wave action detaches Cladophora mats from substrates and causes an intensive secondary pollution of the beaches in the St. Petersburg Resort District. The zoobenthos community is dominated by caddis fly larvae in the shallow littoral. The alien species Dreissena polymorpha in deeper littoral is facilitating filamentous algae growth, clearing the water and recycling nutrients. An important recovery measure in the ecosystem management in the coastal zone is removal of hard substrates from shallow waters to curb the development of filamentous algae. Another important measure is nutrients reduction and control of the $\mathrm{P}: \mathrm{N}$ ratio in the coastal zone of the Gulf of Finland.
\end{abstract}

Key words: Gulf of Finland, estuary, littoral, eutrophication, filamentous algae, Dreissena.

\section{INTRODUCTION}

The littoral zone is a contact area between pelagic and terrestrial ecosystems, which is strongly influenced by different human activities. The coastal zone of the eastern Gulf of Finland is of critical importance for environmental conservation because of various human activities there: trade, municipal economy, industry, traffic, power generation, shipping, agriculture, fisheries, and tourism. Three ports are situated in the eastern Gulf of Finland. One of them (St. Petersburg Port) is the largest for the whole gulf and one of the largest ports for the Baltic

*Corresponding author, golubkov@zin.ru 
Sea. The Neva River is also the largest source of contamination induced by municipalities, industry, and agriculture providing about $60-80 \%$ of the nutrient loads to the Gulf of Finland (Pitkänen et al., 1997; Kondratyev et al., 1997). So the water quality in the coastal zone of the Neva estuary should be a target for ecosystem management in the eastern part of the Gulf of Finland. However, Russian and Finnish hydrobiological studies in 1996-2000 revealed mass development of filamentous algae, which are an important source of secondary pollution of the coastal zone of the eastern gulf (Orlova et al., 1999a).

The invasion of alien species is another serious environmental problem for the Neva estuary (Panov et al., 2001, 2002). Development of persistent fouling communities at near shore habitats in the eastern Gulf of Finland is the result of recent invasions of non-indigenous species from various donor regions (Orlova et al, 1999b). Zebra mussel (Dreissena polymoprha Pallas), the Ponto-Caspian byssate filter-feeding bivalve, which was first found in the Neva estuary in the late 1980s (A. Smurov, pers. comm), is the major constituent of these communities (Orlova et al., 1999a,b; Bäck et al., 2001). This species is likely to have the most profound effect on the functioning of littoral communities in the eastern Gulf of Finland due to its filtering activity and high biomass in the hard-bottom littoral (Orlova et al., 2001).

The purpose of the study was the identification of factors controlling the development of filamentous macroalgae, the quantitative assessment of the role of macroalgae communities in the secondary pollution in the littoral zone of the Neva estuary, and the estimation of the role of zebra mussel beds in biological precipitation and utilization of organic matter, which may facilitate algal blooms through the recycling of bioavailable nutrients.

\section{MATERIAL AND METHODS}

\section{Investigation area}

Investigations were conducted along the northern and southern coasts of the inner and outer parts of the Neva estuary during 2000-02 (Fig. 1). The Neva estuary receives water from the Neva River, which is the major tributary to the Baltic Sea. The catchment area of the Neva River exceeds $280000 \mathrm{~km}^{2}$, and its water discharge averages $2490 \mathrm{~m}^{3} \mathrm{~s}^{-1}$, or $78.6 \mathrm{~km}^{3} \mathrm{yr}^{-1}$. It is the main source of nutrients for the whole Gulf of Finland. Phosphorus input from the Bolshaya Neva, which is the main branch of the Neva River, was $1735 \mathrm{t} \mathrm{yr}^{-1}$ in 2000 and $1095 \mathrm{t} \mathrm{yr}^{-1}$ in 2001. As much as 83-89\% of this phosphorus was of anthropogenic origin (Frumin et al., 2002). Nitrogen input to the Russian part of the eastern Gulf of Finland was 80 900-94 $000 \mathrm{t} \mathrm{yr}^{-1}$ in the 1990s (Kondratyev et al., 1999). Taking into account that mineral phosphorus concentration is a major limiting factor for the algal vegetation along the most part of the Neva estuary like in freshwater ecosystems (Nikulina, 1988) our study was concentrated on phosphorus dynamics. 


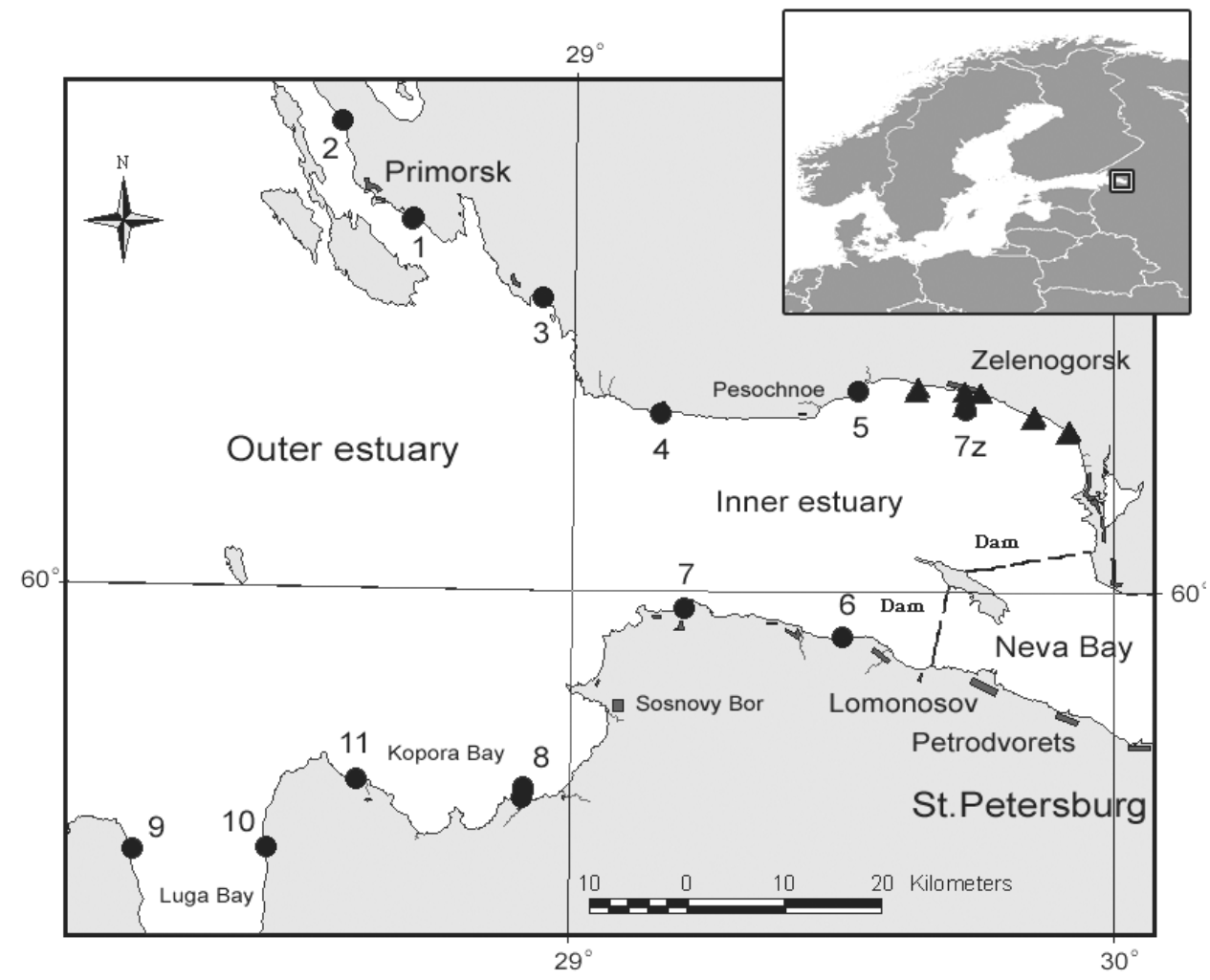

Fig. 1. Sampling stations in the coastal zone of the Neva estuary. Triangles show the sampling stations in the coastal zone near Zelenogorsk. Each triangle corresponds to four stations at depths of $0.5,1.5,3.0$, and $5.0 \mathrm{~m}$.

Neva Bay is a shallow bay with fresh water. It is connected with the lower brackish-water inner and outer estuaries, where salinity reaches 4-6 PSU and depth is up to $40 \mathrm{~m}$. The description of the temperature and salinity regimes in the estuary is provided in Panov et al. (1999), while hydrological features are described in Alenius et al. (1998).

Since the early 1980s freshwater Neva Bay is separated from the estuary's lower brackish water reaches by a storm-surge barrier, which is still under construction (Fig. 1). The storm-surge barrier has got several water-leaking gates in its northern part and a broad ship gate in the southern part.

The coastal zone of the estuary is intensively exploited for recreation (especially along the northern coast in the Resort District of St. Petersburg) and for other human activities including the operation of a nuclear power station near the settlement of Sosnovy Bor. 


\section{METHODS}

The material for the evaluation of the spatial distribution of assemblages living in the littoral and the values of abiotic factors in 2000 was collected at 18 stations along 5 transects and at 3 randomly selected stations in the Resort District of St. Petersburg (vicinity of Zelenogorsk) (Fig. 1). Each transect had 4 sampling stations: at depths of $0.5,1.5,3.0$, and $5.0 \mathrm{~m}$. In 2001 the number of sampling stations in the Zelenogorsk area was diminished to 15 stations. In 2002 samples were taken at station $7 \mathrm{z}$ along the transect at depths of $0.5,1.5,3.0$, and $5 \mathrm{~m}$. Also a field excursion was carried out in July 2002. During this excursion samples were taken at 17 stations along the northern and southern coasts of the eastern Gulf of Finland, including the transect at station 7z (Fig. 1).

For the estimation of seasonal variation in species diversity and quantitative abundance of the littoral benthic assemblages samples were collected every 1 or 2 weeks from May to September 2000 at depths of 0.2 (station 7a) and $0.5 \mathrm{~m}$ (station $7 \mathrm{~b}$ ) at the transect of station 7 situated near Zelenogorsk.

The hard substrates (stones and cobbles) with the attached filamentous algae and associated benthic animals were collected using SCUBA diving. After the sampling the algae were detached from the substrate and their dry weight per square decimetre of substrate was determined. The projective cover of the hard substrates suitable for the growth of filamentous algae was also evaluated from the samples. The zoobenthos samples were sieved in the field through $0.25 \mathrm{~mm}$ mesh, preserved with $4 \%$ formalin, and treated in the laboratory using standard methods. Temperature, conductivity/salinity, water transparency (Secchi disk depth), and the concentrations of chlorophyll $a$ and total phosphorus in the water were determined at all sampling stations. Particulate organic matter (POM) concentrations in the water were determined at the selected stations. The concentration of mineral phosphorus was determined at most sampling stations. Also the input of mineral phosphorus from the brooks in the Zelenogorsk area was determined during the seasons of 2000-01.

Water samples were hydrolyzed with $\mathrm{H}_{2} \mathrm{SO}_{4}$ to evaluate the total phosphorus concentration (Golterman, 1969). Dissolved inorganic phosphorus (DIP) concentration was determined within $12 \mathrm{~h}$ after sample collection using the molybdate "blue" method (Golterman, 1969) or the molybdate method according to the SFS Finnish standard with ascorbic acid as a reducer. The samples for DIP were kept in a refrigerator at the temperature of $+4{ }^{\circ} \mathrm{C}$ before phosphorus determination. Analyses of chlorophyll $a$ concentration were conducted by standard methods, using an extraction in $90 \%$ solution of acetone and then measurements of the density of extracts by means of spectrophotometry (Strickland \& Parsons, 1968). POM concentration was determined by the bichromate method with oxidation in concentrated $\mathrm{H}_{2} \mathrm{SO}_{4}$ according to Giginiak (1979).

The rate of primary production of filamentous algae Cladophora glomerata Kutz. was determined by the oxygen method at station $7 \mathrm{z}$ near Zelenogorsk on 
9-10 July 2002. The algae were cleaned off from stones, carefully washed from detritus and epiphyton in the water, which was sampled in the gulf, and filtered through $100 \mu$ meshes. Then the algae were dried with filter paper, and subsamples of $0.025-0.036 \mathrm{~g}$ wet weight were made. The sub-samples were placed in the light and dark $250 \mathrm{~mL}$ calibrated bottles. The bottles were filled with water from the deep $(5 \mathrm{~m})$ station that had been filtered through $100 \mu$ meshes. The light and dark bottles were exposed in three replicates during $24 \mathrm{~h}$ at the sampling depth. The Winkler method was used to determine the oxygen content in the control bottles at the beginning of the experiment and in the light and dark bottles at the end of the experiments. The photosynthesis rate was recalculated to organic carbon using a factor equal to $0.3 \mathrm{mgC} / \mathrm{mgO}$ for the recalculation of $\mathrm{mgO}$ to $\mathrm{mgC}$ (Håkanson \& Boulion, 2002).

Our field survey of the Dreissena distribution in the Neva estuary covered previously studied (Antsulevich \& Chiviliov, 1992; Orlova \& Panov, 2003) and newly selected shallow water areas in the inner estuary in the Primorsk area (station 1) and in the outer estuary (stations 8 and 10) (Fig. 1). These stations were chosen in order to estimate recent distribution of the zebra mussel beds and reveal areas where $D$. polymorpha is expected to play a sufficient role in the benthic-pelagic coupling.

The balance approach was used for the calculation of the rates of POM precipitation and utilization in the D. polymorpha populations. This approach is based on a balance equation, several basic equations, quantitative abundance and size structure of populations, POM concentration, and temperature in the locality. These equations and the data from the field observations allow estimation of the respiration rate $\left(R, \mathrm{~g} \mathrm{~d}^{-1} \mathrm{~m}^{-2}\right)$, the filtering capacity $\left(F, \mathrm{~m}^{3} \mathrm{~d}^{-1} \mathrm{~m}^{-2}\right)$, the amount of precipitated organic matter for a given time $\left(S, \mathrm{~g} \mathrm{~d}^{-1} \mathrm{~m}^{-2}\right)$, the production $\left(P, \mathrm{~g} \mathrm{~d}^{-1} \mathrm{~m}^{-2}\right)$, the rate of food consumption $\left(C, \mathrm{~g} \mathrm{~d}^{-1} \mathrm{~m}^{-2}\right)$, and the amount of faeces $\left(f, \mathrm{~g} \mathrm{~d}^{-1} \mathrm{~m}^{-2}\right)$ and pseudofaeces $\left(p f, \mathrm{~g} \mathrm{~d}^{-1} \mathrm{~m}^{-2}\right)$ produced in the population during the given time.

The balance equation is

$$
C_{\text {pop }}=\left(P_{\text {pop }}+R_{\text {pop }}\right) / u \text { or } C_{\text {pop }}=\left(A_{\text {pop }}\right) / u,
$$

where $C_{\mathrm{pop}}$ is the rate of food consumption by the population in a given area, $P_{\mathrm{pop}}$ is the rate of production, $R_{\text {pop }}$ is the rate of respiration (both $P_{\text {pop }}$ and $R_{\text {pop }}$ constitute assimilation $\left(A_{\mathrm{pop}}\right)$, the amount of food used by population for metabolism and growth), and $u$ is the efficiency of food utilization.

Both basic equations for respiration (2) and filtration (3) are taken from Alimov (1981):

$$
R_{\text {ind }}=(0.1396 \pm 0.0084) W^{(0.63 \pm 0.04)}\left(\mathrm{mgO} \mathrm{h}^{-1}\right),
$$

where $R_{\text {ind }}$ is respiration and $W$ is fresh body mass of a zebra mussel individual (g);

$$
F_{\text {ind }}=85.5 \pm 0.54 W^{(0.605 \pm 0.066)}\left(\mathrm{mL} \mathrm{h}^{-1}\right)
$$


where $F_{\text {ind }}$ is the rate of filtration and $W$ is fresh body mass of a zebra mussel individual (g).

Using these equations and quantitative data for the population, we calculated the respiration expenses (4); the filtration rate (5), and the rate of precipitation of POM (6) by the population per day at $1 \mathrm{~m}^{2}$ :

$$
R_{\text {pop }}=\Sigma R_{\text {cohort }}=\Sigma\left(R_{\text {ind }} N 24\right)\left(\mathrm{gO} \mathrm{m}^{-2} \mathrm{~d}^{-1}\right),
$$

where $R_{\mathrm{pop}}$ is the respiration in the population; $R_{\text {cohort }}$ is the respiration in the size cohort; 24 is the number of hours; it was assumed after Håkanson \& Boulion (2002) that $1 \mathrm{~g}$ of oxygen is equal to $0.69 \mathrm{~g}$ of organic matter;

$$
F_{\text {pop }}=\Sigma F_{\text {cohort }}=\Sigma\left(F_{\text {ind }} N 12\right)\left(\mathrm{m}^{3} \mathrm{~m}^{-2} \mathrm{~d}^{-1}\right),
$$

where $F_{\text {pop }}$ is the filtration rate in the population; $F_{\text {cohort }}$ is the rate of filtration in each cohort; 12 is the number of hours in a day when freshwater bivalves are believed to filtrate (Alimov, 1981);

$$
S_{\mathrm{pop}}=F_{\mathrm{pop}} C_{\mathrm{POM}}\left(\mathrm{g} \mathrm{m}^{-2}\right),
$$

where $S_{\mathrm{pop}}$ is the quantity of matter precipitated by the population, $C_{\mathrm{POM}}$ is the concentration of POM at the locality $\left(\mathrm{g} \mathrm{m}^{-2}\right)$.

The rate of production $P_{\text {pop }}$ was calculated using the values of respiration expenses in the populations as:

$$
P_{\text {pop }}=0.35 R_{\text {pop }}
$$

$u$ was taken for bivalves as 0.4 after Alimov (1981).

Knowing $S_{\text {pop }}, C_{\text {pop }}$, and $A_{\text {pop }}$ we estimated the production of faeces (8) and pseudofaeces (9) as:

$$
\begin{gathered}
f_{\mathrm{pop}}=C_{\mathrm{pop}}-\left(P_{\mathrm{pop}}+R_{\mathrm{pop}}\right)\left(\mathrm{g} \mathrm{m}^{-2}\right), \\
p f_{\mathrm{pop}}=S_{\mathrm{pop}}-C_{\mathrm{pop}}\left(\mathrm{g} \mathrm{m}^{-2}\right) .
\end{gathered}
$$

We calculated DIP excretion in the zebra mussel populations $\left(D I P_{\text {pop }}\right)$ using the basic equation $D I P_{\text {ind }}=2.77 W_{\text {ind }}^{0.565}\left(R^{2}=0.742, n=21\right.$, P-level $\left.<0.0001\right)$, where $D I P_{\text {ind }}$ is excretion in $\mu \mathrm{P} \mathrm{h}^{-1}$ per an individual, and $W$ is the individual's fresh body mass in $\mathrm{g}$. This equation was received in an experimental study carried out by Orlova et al. (accepted pending revision). The average data on the abundance and the biomass in the populations as well as the size structure of the populations were used for the calculation of the excretion as: $D I P_{\text {pop }}=$ $\Sigma D I P_{\text {cohort }}=\Sigma\left(D I P_{\text {ind }} N 24\right),\left(\mathrm{mgP} \mathrm{m}^{-2} \mathrm{~d}^{-1}\right)$, where $D I P_{\text {cohort }}$ is the excretion in each size cohort; $W$ is the average fresh body mass for the representatives of each cohort (g), and $N$ is the number of individuals in the cohort; 24 is the number of hours.

To evaluate the effect of non-predatory zoobenthos on the growth of filamentous algae we also used the balance equation: $C=(P+D) / u$, where $C$ is the rate of food consumption by bottom animals, $P$ is their production rate, $D$ is 
the rate of decomposition of organic matter by zoobenthos, and $u$ is the efficiency of food utilization. The efficiency of food utilization of grazing animals $(u)$ was assumed to be 0.6 (Golubkov, 2000). To calculate the rate of decomposition of organic matter $\left(R, \mathrm{gC} \mathrm{d}^{-1}\right)$ by zoobenthos the following equations of relationships between the respiration rate $\left(R, \mathrm{mLO} \mathrm{h}^{-1}\right)$ and body mass of animals $(W, \mathrm{~g})$ at the temperature of $20^{\circ} \mathrm{C}$ were used:

$\begin{array}{ll}\text { Oligochaeta } & R_{20}=0.105 W^{0.750} \text { (Kamluk, 1974), } \\ \text { Hirudinea } & R_{20}=0.147 W^{0.820} \text { (Kamluk, 1974), } \\ \text { Gastropoda } & R_{20}=0.099 W^{0.770} \text { (Alimov et al, 1988), } \\ \text { Bivalvia } & R_{20}=0.098 W^{0.630} \text { (Alimov, 1981), } \\ \text { Amphipoda } & R_{20}=0.142 W^{0.790} \text { (Suschenya, 1972), } \\ \text { Trichoptera } & R_{20}=0.263 W^{0.818} \text { (Golubkov, 1986), } \\ \text { Chironomidae } & R_{20}=0.088 W^{0.750} \text { (Balushkina, 1987). }\end{array}$

The mean body mass of different groups of animals found in the samples was used for $R_{20}$ calculations. The $R$ values obtained at the temperature of $20^{\circ} \mathrm{C}$ were recalculated to the water temperatures observed in the gulf using the temperature coefficient $Q_{10}$, which was accepted as 2.25 (Winberg, 1983): $R=R_{20} 2.25^{((T-20) / 10)}$. The decomposition of organic matter by zoobenthic communities was calculated as $D=\sum R k N 24$, where $N$ is the abundance of different animal groups, $k$ is a factor for recalculating respiration in mLO to $\mathrm{mgC}$, which is equal to $0.43 \mathrm{mgC} / \mathrm{mLO}$ (Håkanson \& Boulion, 2002).

The animal production was assumed to be $P=C B$, where $C$ is the specific rate of production and $B$ is the biomass of bottom animals. The specific rate of production by aquatic insects was calculated after Golubkov (2000) and Amphipoda after Panov (1988):

Trichoptera $\quad C=0.0130 e^{0.054 T}$,

Chironomidae $C=0.0087 e^{0.142 T}$,

Amphipoda $C=-0.044+0.239 W^{-0.36}$.

For Oligochaeta and Hirudinea $C$ was accepted as 0.03 (Finogenova \& Lobasheva, 1987). For Gastropoda it was assumed to be 0.01 and for Bivalvia, 0.025 (Alimov et al., 1988).

\section{RESULTS}

Cladophora glomerata dominated greatly among filamentous algae in the Neva estuary during the study period. Its average biomass in the shallow littoral $(0.5 \mathrm{~m} \mathrm{depth})$ in the Resort District of St. Petersburg was about $100 \mathrm{~g} \mathrm{~m}^{-2}$ dry weight, which was the maximum value per square metre of the bottom (Fig. 2). As depth increased, the biomass of $C$. glomerata decreased due to lower light penetration and a diminution of the projective cover of the bottom by hard substrates at the larger depth in this region. Our visual evaluation of the projective cover of hard substrates gave the average of about $90 \%$ at a depth of $0.5 \mathrm{~m}$ and $60 \%$ and $40 \%$ at 1.5 and $3.0 \mathrm{~m}$, respectively. 


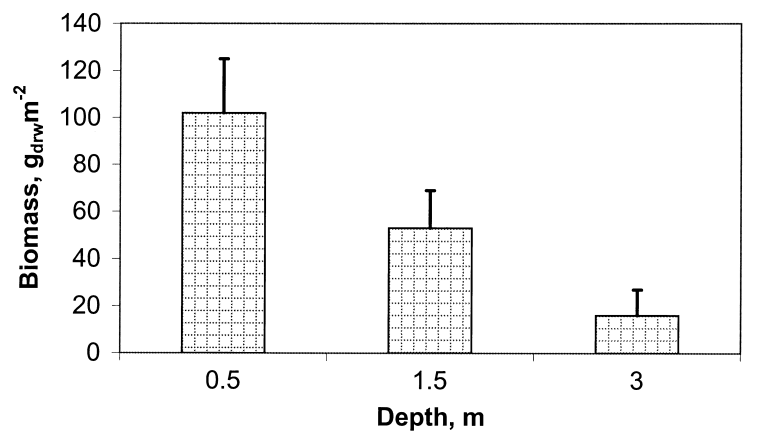

Fig. 2. Average biomass of filamentous algae Cladophora glomerata in the northern littoral in the Zelenogorsk area in 2001.

The primary production of $C$. glomerata was very high at the shallow littoral (Fig. 3). As depth increased, the primary production of $C$. glomerata decreased due to lower light penetration. Secchi depth was $1.3 \mathrm{~m}$ at station $7 \mathrm{z}$ at the time of the experiment. Wave action affects dramatically the growing algae. As a result of the heavy storms the filamentous algae were detached from the stones almost entirely several times through the observation period, and algal biomass on the hard substrates considerably decreased (Fig. 4). Nevertheless, the Cladophora easily recovered its biomass due to fast growth in the conditions of full illumination in the shallow littoral and high water temperature in summer.

The evaluation of Cladophora biomass on the hard substrates along the northern and southern coasts of the eastern Gulf of Finland was conducted in July 2002. It was shown that the algal biomass at the southern coast of the eastern Gulf of Finland was considerably higher than at its northern coast (Table 1). The biomass of $C$. glomerata reached $370-530 \mathrm{~g} \mathrm{dw}$ per $\mathrm{m}^{2}$ of hard substrate at a depth of $1.5 \mathrm{~m}$ at stations 7 and 8 situated in the southern littoral near Sosnovy Bor (Fig. 1).

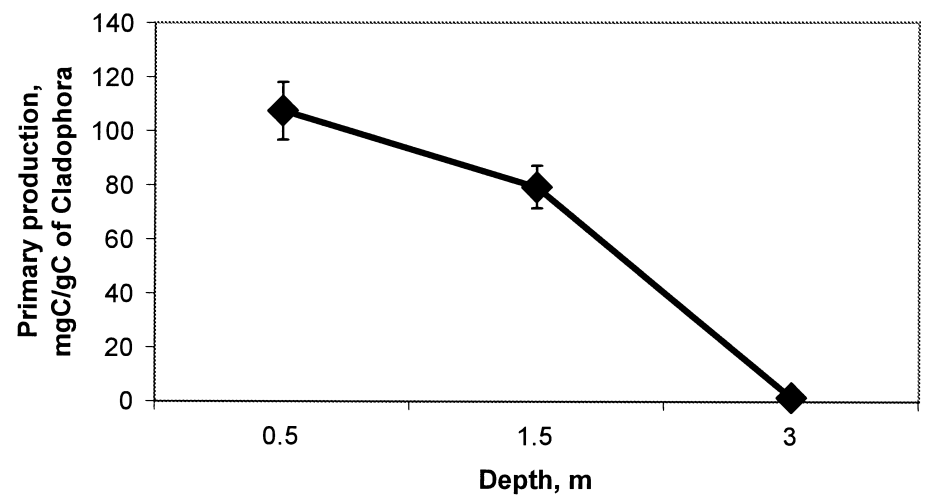

Fig. 3. Primary production of filamentous algae Cladophora glomerata in the northern littoral of the Neva estuary in July 2002. 


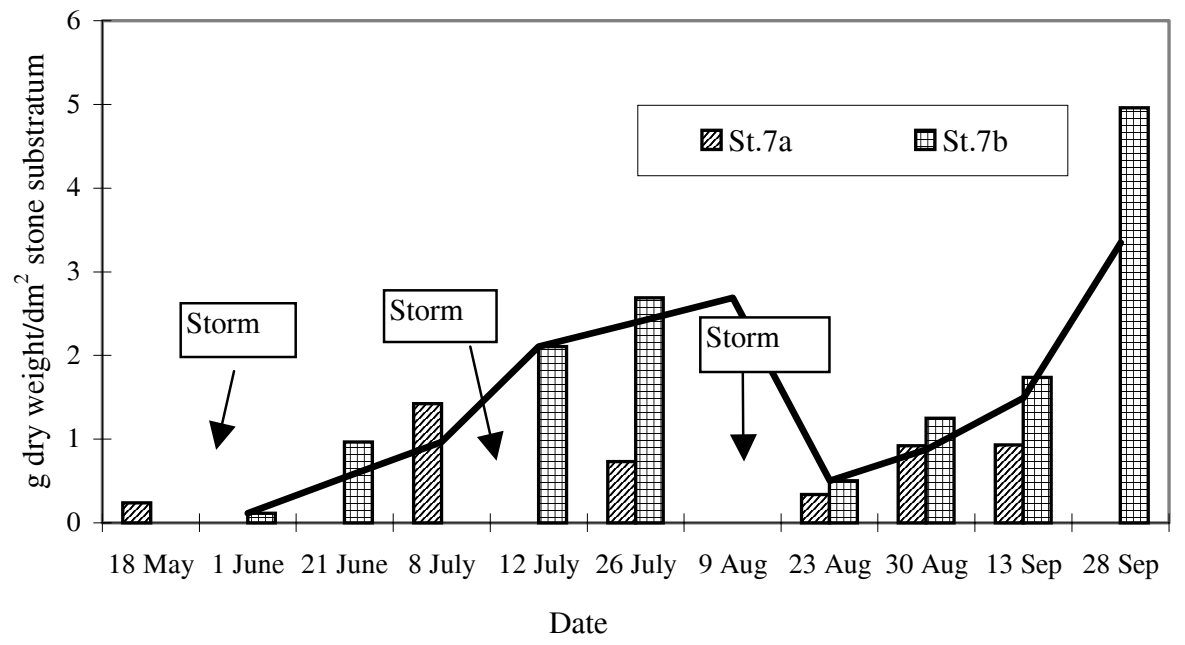

Fig. 4. Seasonal variation in the biomass of Cladophora glomerata on stones at depths of 0.2 (station 7a) and $0.5 \mathrm{~m}$ (station $7 \mathrm{~b}$ ) in the northern littoral of the Neva estuary near Zelenogorsk in 2000.

Table 1. Environmental variables and biomass of Cladophora in the northern and southern littorals of the Neva estuary

\begin{tabular}{lc|c}
\hline \multicolumn{1}{c|}{ Variable } & Northern littoral & Southern littoral \\
\hline Salinity, PSU & 1.08 & 2.51 \\
Secchi depth, $\mathrm{m}$ & 0.83 & 2.45 \\
Chlorophyll $a$ in plankton $\pm \mathrm{SD}, \mathrm{mg} \mathrm{m}^{-3}$ & $16.44 \pm 11.54$ & $2.12 \pm 0.65$ \\
Total phosphorus in plankton $\pm \mathrm{SD}, \mathrm{mg} \mathrm{m}^{-3}$ & $79.70 \pm 31.74$ & $45.00 \pm 8.08$ \\
Biomass of Cladophora $\pm \mathrm{SD}, \mathrm{g} \mathrm{dm}^{-2}$ of & $1.72 \pm 0.58$ & $3.68 \pm 1.53$ \\
$\quad$ substrate & &
\end{tabular}

On the contrary, the chlorophyll $a$ and total phosphorus concentrations were considerably higher at the northern coast of the Neva estuary (Table 1). The chlorophyll $a$ concentrations were in the range $3.8-31.47 \mathrm{mg} \mathrm{m}^{-3}$ along the northern coast and $1.47-2.94 \mathrm{mg} \mathrm{m}^{-3}$ along the southern coast of the Neva estuary. The total phosphorus concentration ranged from 32 to $138 \mathrm{mg} \mathrm{m}^{-3}$ in the northern littoral and from 34 to $52 \mathrm{mg} \mathrm{m}^{-3}$ in the southern littoral of the eastern Gulf of Finland. The average Secchi depth along the northern coast was only $0.83 \mathrm{~m}$ but $2.45 \mathrm{~m}$ at the opposite side of the gulf.

The biomass of bottom animals associated with hard substrates in the shallow littoral $(0.5 \mathrm{~m})$ at station $7 \mathrm{z}$ near Zelenogorsk (where the maximum growth of filamentous algae was observed) was $20.38-62.21 \mathrm{~g} \mathrm{~m}^{-2}$ during the 2000 research period (Fig. 5). Caddis fly Hydropsyche contubernalis borealis MacLachlan and leach Erpobdella octoculata (L.) dominated in the biomass of bottom animals in the shallow littoral. Dreissena polymorpha was the dominant taxon in the deeper waters. 
The most important functional groups of non-predatory zoobenthos in the shallow littoral were chironomids, caddis fly larvae, and amphipods. The mean combined rate of food consumption of these taxa during the season was $225 \mathrm{mgC} \mathrm{m}^{-2} \mathrm{~d}^{-1}$. This is about 20 times lower than the average rate of C. glomerata primary production at this station. Calculations of the phosphorus excretion by zoobenthos (Fig. 5) showed that bottom animals at a depth of $0.5 \mathrm{~m}$ excrete on average $3.44 \mathrm{mgP} \mathrm{m} \mathrm{d}^{-1}$ or $6.88 \mathrm{mgP} \mathrm{m}^{-3} \mathrm{~d}^{-1}$. Taking into account that the concentration of mineral phosphorus in the water at this depth was only $3-10 \mathrm{mgP} \mathrm{m}^{-3}$ in summer, we may conclude that bottom animals play an important role in the nutrient cycling at this locality.

The density and biomass of the zebra mussel populations along the northern transects (at stations 1 and 7z) were relatively high in July 2002 (Table 2), with both values showing a statistically significant increase in the deeper waters (1-way ANOVA for the density is $F(2,12)=3.671, p<0.057$ and for the biomass,

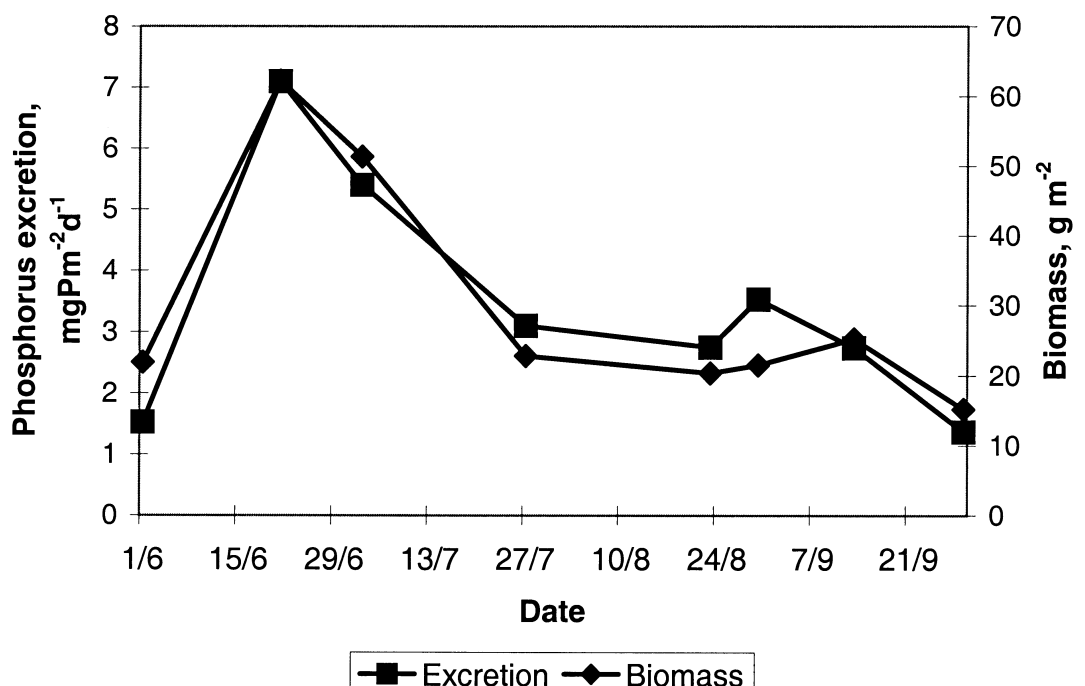

Fig. 5. Biomass and phosphorus excretion of zoobenthos at a depth of $0.5 \mathrm{~m}$ near Zelenogorsk (station $7 \mathrm{z}$ ) in 2000.

Table 2. Density ( $\mathrm{N}$, ind. $\left.\mathrm{m}^{-2}\right)$ and biomass $\left(\mathrm{B}, \mathrm{g} \mathrm{m}^{-2}\right.$ ) of Dreissena polymorpha populations (average \pm SE) at different depths in July 2002 along transects at the sampling stations $7 \mathrm{z}$ and 1 (northern coast) and 8 and 10 (southern coast) in the eastern Gulf of Finland

\begin{tabular}{|c|c|c|c|c|c|c|}
\hline \multirow{2}{*}{ Transect } & \multicolumn{2}{|c|}{$1.5 \mathrm{~m}$} & \multicolumn{2}{|c|}{$3 \mathrm{~m}$} & \multicolumn{2}{|c|}{$5 \mathrm{~m}$} \\
\hline & $\mathrm{N}$ & $\mathrm{B}$ & $\mathrm{N}$ & $\mathrm{B}$ & $\mathrm{N}$ & $\mathrm{B}$ \\
\hline $7 \mathrm{z}$ & $5 \pm 5$ & $7.3 \pm 7.3$ & $969 \pm 242$ & $806.7 \pm 162.2$ & $576 \pm 170$ & $608 \pm 198.7$ \\
\hline 1 & $1056 \pm 249$ & $437.7 \pm 78.3$ & $2805 \pm 733$ & $1340.3 \pm 337.2$ & \multicolumn{2}{|c|}{ Sandy bottoms } \\
\hline 8 & $101 \pm 54$ & $2.7 \pm 1.5$ & $117 \pm 38$ & $4.2 \pm 2.9$ & $16 \pm 16$ & $10 \pm 10$ \\
\hline 10 & \multicolumn{2}{|c|}{ Dead byssus } & \multicolumn{2}{|c|}{ Dead byssus } & \multicolumn{2}{|c|}{ Dead byssus } \\
\hline
\end{tabular}


$F(2,12)=3.179, p<0.0089$ ). On the contrary, along both southern transects (at stations 8 and 10) the quantitative development of $D$. polymorpha was very low or absent (Table 2), despite the availability of hard substrates and water salinity within tolerance limits. This difference in the zebra mussel distribution between the two shores is reliably confirmed statistically by $t$-tests for the density $(t(22)=$ $2.691, p=0.0133)$ and the biomass $(t(22)=3.530, p=0.0018)$. No depthdependent variation was found for the density $(1$-way ANOVA: $F(2,6)=1.908$, $p<0.228$ ) and the biomass (1-way ANOVA: $F(2,6)=0.404, p<0.684$ ) along the transect at station 8 . Thus, considering the observed quantitative development of the zebra mussel, the populations along the northern coast in the inner Neva estuary are expected to impact water quality. In the Resort District (the most intensively studied area) the zebra mussel settlement covers $4.7 \mathrm{~km}^{2}$ along the distance of $17 \mathrm{~km}$ of the littoral zone, and its total biomass reached 6510 tonnes in fresh weight in July 2001 (Orlova et al., accepted, pending revision).

Temporal and spatial variations in the daily DIP released by the zebra mussels along the transect at station $7 \mathrm{z}$ are presented in Fig. 6. The maximum DIP excretion was observed in July 2001, which corresponds to the highest abundance of this species. The rate of POM precipitation varied from 0.5 to $2.5 \mathrm{~g} \mathrm{~m}^{-2} \mathrm{~d}^{-1}$ during the observation period (Fig. 7). Taking into account that $17 \mathrm{~km}$ of the Resort District shoreline harbours a significant zebra mussel biomass, the total calculated amount of precipitated POM could reach 15.023 tonnes per day at maximum quantitative development of Dreissena beds in July 2001. However, normally less than 50\% of the precipitated POM is assimilated by mussels, while the rest of the precipitated particles are transformed into faeces and easily stirring up pseudofaeces. The latter item of balance is a result of selective sorting of particles on ctenidia. This matter passes through the mantle cavity, being enveloped with mucus, and then it is thrown out without any digestion (Fig. 7).

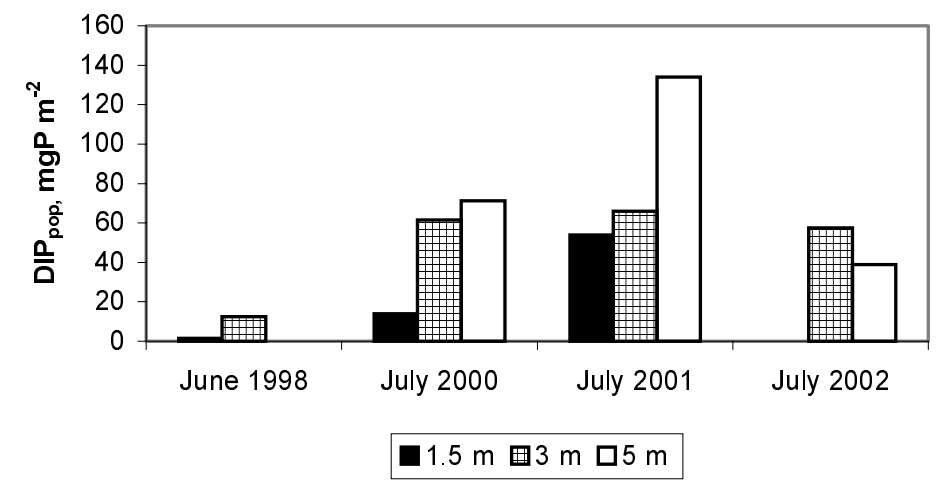

Fig. 6. Spatial and temporal variations in dissolved inorganic phosphorus (DIP) excretion by the Dreissena population at station $7 \mathrm{z}$ in the Resort District of the inner Neva estuary. 


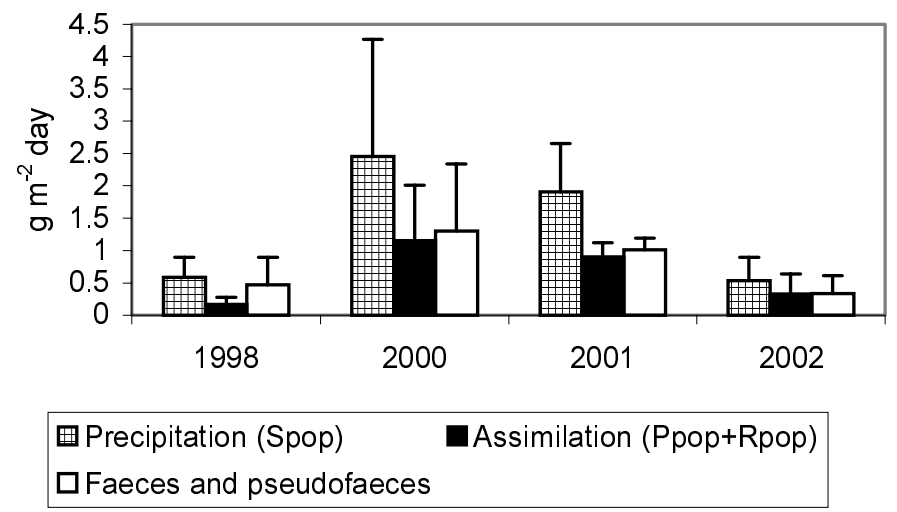

Fig. 7. Main items of biotic balance for Dreissena populations at station $7 \mathrm{z}$ in the Resort District of the inner Neva estuary.

\section{DISCUSSION}

Eutrophication and alien species are the main environmental problems for the Neva estuary (Panov et al., 2002), as for the most of the Baltic coastal ecosystems (Schernewski \& Schiewer, 2002). Moreover, the two problems are often closely interconnected, because invasion of alien species leads in some cases to acceleration of eutrophication processes (Zmudzinski, 1996; Leppäkoski et al., 2002).

According to our estimations the primary production of filamentous algae C. glomerata in the eastern Gulf of Finland may reach $100 \mathrm{mgC} / \mathrm{gC}$ of Cladophora per day (Fig. 2). The average biomass of this species in the shallow littoral (0.5 m depth) of the Resort District of St. Petersburg near Zelenogorsk (Fig. 1) is about $100 \mathrm{~g} \mathrm{~m}^{-2}$ (Fig. 2). Taking into account that dry biomass of algae contains about $46 \%$ of carbon (Boulion, 1979), we may assume that the primary production of C. glomerata in this area was about $4.6 \mathrm{gC} \mathrm{m}^{-2} \mathrm{~d}^{-1}$. This is considerably higher than the primary production of the open waters of the eastern Gulf of Finland, whose average rate for the whole estuary was about $0.58 \mathrm{gC} \mathrm{m}^{-2} \mathrm{~d}^{-1}$ in the middle of the 1980s (Shishkin et al., 1989) and reached $2.3 \mathrm{gC} \mathrm{m}^{-2} \mathrm{~d}^{-1}$ in the inner part of the estuary by the beginning of the $2000 \mathrm{~s}$ (Golubkov et al., 2003).

Wave action affects growing algae dramatically. As a result of the storms great masses of filamentous algae are detached from the stones and spoil the coastal zone of the Neva estuary. This causes intensive secondary pollution of the coast and creates serious problems for the recreation and tourism in the Resort District of St. Petersburg. The storm casts consisting of filamentous algae may reach 2 tonnes of wet weight per $100 \mathrm{~m}$ of the shoreline. Therefore, eutrophication of the eastern Gulf of Finland is more intensive in the coastal zone than in the open waters of the Neva estuary. 
Comparison of the biomass of C. glomerata along the northern and southern coasts showed that the growth of filamentous algae on hard substrates in the southern littoral is even higher than in the northern littoral of the estuary (Table 1). One of the reasons for this difference may be the relatively low transparency of the water along the northern coast as compared with the water near the southern coast. This is connected with the vigorous growth of phytoplankton in the northern part of the Neva estuary, as indicated by the chlorophyll $a$ concentration (Table 1).

The more intensive growth of the phytoplankton in the northern part of the estuary could be explained by hydrological features. Most of the fresh water from the Neva River, which accounts for $93 \%$ of the water draining to the Russian part of the eastern Gulf of Finland (Kondratyev et al., 1997), flows along the northern coast of the gulf supplying primary producers with nutrients. As a result, the concentration of total phosphorus in the water along the northern coast is much higher than along the southern coast of the Neva estuary (Table 1). Massive bluegreen blooms happened in shallow water along the northern coast of the Gulf of Finland from Pesochnoe to the town of Primorsk in July 2002. The dominant species was Anabaena flos-aquae Bréb. An apparent toxic effect of the bluegreen blooms was also observed.

Thus, there are two alternative consequences of the eutrophication process in the coastal zone of the eastern Gulf of Finland: one is mass occurrence of filamentous algae and the other is phytoplankton blooms. The development of phytoplankton may prevent massive development of filamentous algae, which is the main source of the secondary pollution in the coastal zone, but in the case of phosphorus excess it may lead to toxic blue-green algal blooms. Therefore, the management of the $\mathrm{P}: \mathrm{N}$ ratio in the coastal water is one of the key environmental problems in the eastern Gulf of Finland. Some specific methods for preventing blue-green blooms were developed for instance in North America (Barica et al., 1980).

There is also another method to prevent filamentous algal blooms in the near shore waters. One of the main factors facilitating the growth of Cladophora glomerata is the abundance of hard substrates in this zone. So an important measure of ecosystem management is removal of stones from the shallow littoral. Unfortunately, local managers apply quite the opposite management methods bringing stones from the land to the shallow waters to make the sands on the beaches more stable.

An important biotic factor, which may potentially affect the development of filamentous algae, is the grazing of bottom animals (Golubkov \& Anokhina, 1992). Our data show that at present the food consumption of grazing species is much lower than the primary production of filamentous algae, and, therefore, has no real impact on their development. On the other hand, the establishment and progressive development of the population of new alien gammarid species Gmelinoides fasciatus (Stebbing), which effectively consumes Cladophora glomerata (Berezina \& Panov, 2002), may increase the importance of this factor in the future. 
Bottom animals also play an important role in nutrient cycling. They excrete about $7 \mathrm{mgP} \mathrm{m}^{-2}$ or $14 \mathrm{mgP} \mathrm{m}^{-3}$ per day at a depth of $0.5 \mathrm{~m}$ near Zelenogorsk in June (Fig. 4). At the same time the concentration of mineral phosphorus in the water at this depth is about $10 \mathrm{mgP} \mathrm{m}{ }^{-3}$. Our data show also that the alien mussel Dreissena polymorpha plays a very important role in nutrient cycling. The biomass of this species reaches $1.5 \mathrm{~kg} \mathrm{~m}^{-2}$ (Table 2) and phosphorus excretion 50-200 $\mathrm{mg} \mathrm{m}^{-2}$ per day (Fig. 6) in the Resort District of St. Petersburg at depths of 3-5 m just below the Cladophora belt. This constitutes up to $50 \%$ of the total phosphorus in this zone.

The recently observed abundance of the zebra mussel along the northern coast of the inner Neva estuary is close to the values observed in other Baltic inlets, such as the Odra estuary (Szczecin Lagoon) (Wictor, 1969; Fenske, 2002). Comparison of the above-mentioned calculated release of bioavailable inorganic nutrients from the zebra mussel with the phosphorus concentration in the inner Neva estuary shows it to be comparable with other powerful factors responsible for nutrient releases in marine ecosystems such as fouling communities in coastal areas of seas, coastal upwelling systems, and highly productive wetlands. For example, according to Kautsky \& Wallentinus (1980) blue mussel beds in the coastal zone of the northern Baltic Proper can release 104 tonnes of inorganic phosphorus a year per an area of $160 \mathrm{~km}^{2}$, where the biomass of blue mussels reaches 10200 tonnes in dry weight. The results provided by Dale \& Prego (2002) for Pontevedra ria, NW Spain, show that inorganic nitrogen fluxes in the sediment-water interface are positive and reach 6-7 $\mu \mathrm{mol} \mathrm{NO}{ }_{3}^{-} \mathrm{m}^{-2} \mathrm{~h}^{-1}$ and $65-70 \mu \mathrm{mol} \mathrm{NH} \mathrm{N}_{4} \mathrm{~m}^{-2} \mathrm{~h}^{-1}$ in coastal upwelling systems. $\mathrm{PO}^{-3}{ }_{4}$ fluxes observed by Baudinet et al. (1990) for the Gulf of Fos (France) were positive and the highest at the localities with blue mussel settlements, where they reached $116 \mu \mathrm{mol} \mathrm{m}{ }^{-2} \mathrm{~h}^{-1}$, while $\mathrm{NH}_{4}$ fluxes

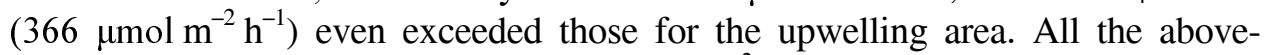
mentioned values are comparable with $\mathrm{PO}^{-3}{ }_{4}$ fluxes observed in the most productive ecosystems of salt marshes, which vary from 100 to $1270 \mu \mathrm{mol} \mathrm{m} \mathrm{m}^{-2}$ (Coleau, 1988, cited in Baudinet et al., 1990) and are higher than any other value given in the review table in Baudinet et al. (1990).

Taking into account the high rate of POM precipitation by the zebra mussel populations we do not exclude an indirect facilitation of Cladophora vegetation through their water clearing effect. This effect can be compared with that observed in previously invaded regions of the Baltic Sea. For example, the daily amount of the precipitated organic matter here is similar to that reported by Wictor (1969) for the Szczecin Lagoon where it reaches 53 tonnes per hour for the whole area of $687 \mathrm{~km}^{2}$. Taking into account that the zebra mussel covers $20-30 \%$ of the total area of the lagoon (Fenske, 2002) one may conclude that the rate of POM sedimentation by this species is as high as 3.1-4.6 $\mathrm{g} \mathrm{m}^{-2} \mathrm{~d}^{-1}$. This is close to our estimation for the transect at station $7 \mathrm{z}$ of the Resort District of St. Petersburg, which is 0.5 to $2.5 \mathrm{~g} \mathrm{~m}^{-2} \mathrm{~d}^{-1}$.

Generally the role of newly established Dreissena beds in the benthic-pelagic coupling in the inner Neva estuary can be compared with the importance of 
sessile mussels (Bivalvia) and other hard bottom foulers (Cirripedia, Bryozoa, and Polychaeta) that are typical of coastal marine ecosystems (Railkin, 1998; Dolmer \& Frandsen, 2002; Bedman et al., 2002). Because of their dominance in marine fouling communities, seston-feeders are the main contributors into the benthic-pelagic coupling, consuming up to $90 \%$ of the daily pelagic production (Arntz et al., 1999).

Thus, our data show that the coastal zone of the eastern Gulf of Finland suffers from intensive eutrophication due to the P loading from St. Petersburg. This brings about an intensive development of filamentous algae Cladophora glomerata. This species is the main source of secondary pollution in the coastal zone, together with periodical blue-green algal blooms. An important measure in ecosystem management is removal of hard substrates from the shallow littoral zone as these proliferate Cladophora growth. Establishment of Dreissena beds may greatly contribute to nutrients cycling and algae growth. However, the growth of the population of new alien gammarid species may restrict the abundance of filamentous algae in the future. The development of phytoplankton may prevent massive filamentous algal blooms, but in the case of phosphorus excess it may lead to the proliferation of toxic blue-green algae. Another important direction of ecosystem management should be the reduction of nutrients and control of the $\mathrm{P}: \mathrm{N}$ ratio in the coastal zone of the Gulf of Finland.

\section{ACKNOWLEDGEMENT}

The present study was supported by the Finnish Ministry of the Environment, Maj and Tor Nessling Foundation, RFBR projects 00-15-97825 and 02-04-48646, and Russian Programmes on Biodiversity and Bioresources.

\section{REFERENCES}

Alenius, P., Myrberg, K. \& Nekrasov, A. 1998. Physical oceanography of the Gulf of Finland: a review. Boreal Environ. Res., 3, 97-125.

Alimov, A. F. 1981. Functional Ecology of Freshwater Bivalves. Nauka, Leningrad (in Russian).

Alimov, A. F., Arakelova, E. S. \& Vlasova, V. G. 1988. Structural and functional characteristics of gastropod and bivalve mussels. In Communities of the Freshwater Invertebrates Among Macrophytes Association (Alimov, A. F., ed.). Proc. Zool. Inst. USSR AS, 186, 41-53 (in Russian).

Antsulevich, A. E. \& Chiviliov, S. M. 1992. Modern state of Luga Inlet benthic fauna of the Gulf of Finland. Vestn. Leningr. univ., Biol. Ser. 3, 17, 3-7 (in Russian).

Arntz, W. E., Gili, G. M. \& Reise, K. 1999. Unjustifiably ignored: reflection on the role of benthos in marine ecosystems. NATO ASI Ser., Ser. E: Appl. Sci., 59, 105-124.

Bäck, S., Orlova, M., Panov, V., Telesh, I., Anokhina, L., Ignatieva, N., Nekrasov, A., Kovaltchouk, N. \& Dernjatin, M. 2001. Cladophora glomerata and Dreissina polymorpha in the Neva estuary, Gulf of Finland, Baltic Sea. In EU-LIFE ALGAE: New Approaches to Combat Macroalgae Blooms, Göteborg, Sweden, 9-12 May, 2001. Book of Abstracts, p. 6. 
Balushkina, E. V. 1987. Functional Importance of Chironomid Larvae in Continental Reservoirs. Nauka, Leningrad (in Russian).

Barica, J., Kling, H. \& Gibson, J. 1980. Experimental manipulation of algal bloom composition by nitrogen addition. Can. J. Fish. Aquat. Sci., 37, 1175-1183.

Baudinet, D., Alliot, E., Berlang, B., Grenz, C., Plante-Cuny, M.-R., Plante, R. \& Salen-Picard, C. 1990. Incidence of mussel culture on biogeochemical fluxes at the sediment-water interface. Hydrobiologia, 207, 187-196.

Bedman, H. A., Willows, R. I. \& Kaiser, M. J. 2002. Potential application of mussel modeling. Helgoland Mar. Res., 56, 76-85.

Berezina, N. A. \& Panov, V. E. 2002. Changes in the Neva Estuary littoral communities as a result of establishment of new gammarid species. In "The Gulf of Finland Symposium”, Tallinn, 28-30 October 2002, Abstracts, p. 8.

Boulion, V. V. 1979. Primary production of plankton. In General Fundamentals of Water Ecosystems Studies (Winberg, W. W., ed.), pp. 187-199. Nauka, Leningrad.

Dale, A. W. \& Prego, R. 2002. Physico-biogeochemical controls on benthic-pelagic coupling of nutrient fluxes and recycling in a coastal upwelling system. Mar. Ecol. Progr. Ser., 235, $15-28$.

Dolmer, P. \& Frandsen, R. P. 2002. Evaluation of Danish mussel fishery: suggestions for an ecosystem management approach. Helgoland Mar. Res., 56, 13-20.

Fenske, C. 2002. The ecological importance of mussels, their effect on water quality and their possible use for coastal management. In Baltic Coastal Ecosystems. Structure, Function and Coastal Zone Management (Schernewski, G. \& Schiewer, U., eds.), pp. 53-65. CEEDES-Ser., Springer, Berlin.

Finogenova, N. P. \& Lobasheva, T. M. 1987. Growth of Tubifex tubifex Muller (Oligochaeta, Tubificidae) under various trophic conditions. Int. Rev. Hydrobiol., 72, 709-726.

Frumin, G. T., Basova, S. L., Kobelevan, N. I. \& Leonova, M. V. 2002. Ecological problems of the eastern Gulf of Finland. In "The Gulf of Finland Symposium”, Tallinn, 28-30 October 2002, Abstracts, p. 10.

Giginiak, Y. G. 1979. Calorific value of aquatic invertebrates. In General Principles of Aquatic Ecosystems' Research (Vinberg, G. G., ed.), pp. 43-57. Nauka, Leningrad (in Russian).

Golterman, H. L. (ed.) 1969. Methods for chemical analysis of freshwaters. IBP Handbook, No 8. Blackwell Sci. Publ., Oxford and Edinburgh.

Golubkov, S. M. 1986. Relationships between the respiration rate and body mass of aquatic insects. Hydrobiol. J., 22, 80-88.

Golubkov, S. M. 2000. Functional ecology of aquatic insects. Proc. Zool. Inst. (Leningr.), 284 (in Russian).

Golubkov, S. M. \& Anokhina, L. E. 1992. The effect of grazing by mayfly larvae on the species composition, diversity and primary production of periphyton. Russ. J. Aquat. Ecol., 1, 137142.

Golubkov, S. M., Alimov, A. F., Telesh, I. V., Anokhina, L. E., Maximov, A. A., Nikulina, V. N., Pavel'eva, E. B. \& Panov, V. E. 2003. Functional response of midsummer planktonic and benthic communities in the Neva Estuary (eastern Gulf of Finland) to anthropogenic stress. Oceanologia, 45(1), 53-66.

Håkanson, L. \& Boulion, V. V. 2002. The Lake Foodweb - Modeling Predation and Abiotic/Biotic Interactions. Backhuys Publishers, Leiden.

Kamluk, L. V. 1974. Respiration of free living flat and annelid worms. J. Gen. Biol., 35, 874-885 (in Russian).

Kautsky, N. \& Wallentinus, I. 1980. Nutrient release from a Baltic Mytilus-red algae community and its role in benthic and pelagic productivity. Ophelia, Suppl. 1, 17-30.

Kondratyev, S., Yefremova, L., Sorokin, I., Alyabina, G. \& Chernykh, O. 1997. External load on Russian part of the Gulf of Finland: seasonal dynamics of riverine inputs and atmospheric deposition in 1995-1996. In Proc. of the Final Seminar of the Gulf of Finland Year 1996 (Sarkkula, J., ed.), pp. 19-29. Suomen Ympäristökeskus, Helsinki. 
Kondratyev, S., Gronskaya, T. P., Sorokin, I. N., Alyabina, G. A., Yefremova, L. V. \& Ignatyeva, N. V. 1999. External load on the Gulf of Finland. In The Gulf of Finland under Anthropogenic Impact (Rumiansev, B. A. \& Drabkova, V. G., eds.), pp. 304-354. Russian Academy of Sciences, St. Petersburg.

Leppäkoski, E., Olenin, S. \& Gollasch, S. 2002. The Baltic Sea - a field laboratory for invasion biology. In Alien species in European Waters (Leppäkoski, E., Olenin, S. \& Gollasch, S., eds.), pp. 253-259. Kluwer Publishers, Netherlands.

Nikulina, V. N. 1988. Nutrients as limiting factor for phytoplankton. In Hydrobiological Research (Skarlato, O. F., ed.), pp. 11-19. Zoological Institute, Leningrad (in Russian).

Orlova, M. I. \& Panov, V. E. 2003. Establishment of the zebra mussel, Dreissena polymorpha Pallas in the Neva Estuary (Gulf of Finland, Baltic Sea): distribution, population structure and possible impact on local unionid bivalves. Hydrobiologia (in press).

Orlova, M. I., Anokhina, L. E., Panov, V. E., Nekrasov, A. V. \& Klimentenok, S. N. 1999a. Preliminary environmental state assessment for littoral zone in Resort District of St. Petersburg. Balt. Float. Univ. Res. Bull., 3, 37-45.

Orlova, M. I., Panov, V. E., Krylov, P. I., Telesh, I. V. \& Khlebovich, V. V. 1999b. Changes in planktonic and benthic communities of the eastern part of the Gulf of Finland caused by biological invasions. Proc. Zool. Inst. RAS, 279, 305-325 (in Russian).

Orlova, M. I., Anokhina, L. E., Golubkov, S. M., Ignatieva, N. V. \& Klimentenok, S. N. 2001. Distribution, biological peculiarities and impacts of Dreissena polymorpha Pallas in the Neva Estuary (Eastern Gulf of Finland, Baltic Sea). In Abstracts of Baltic Sea Science Congress 2001, Past, Present and Future - A Joint Venture, November 25-29, Stockholm, p. 264.

Orlova, M. I., Golubkov, S. M., Ignatieva, N. V. \& Kalinina, L. A. Accepted, pending revision. Dreissena polymorpha in the Neva Estuary: is it a biofilter or source for pollution? Mar. Poll. Bull.

Panov, V. E. 1988. Growth and production of amphipods. In Communities of the Freshwater Invertebrates Among Macrophytes Associations (Alimov, A. F., ed.), pp. 150-160. Proc. Zool. Inst. USSR AS, 186 (in Russian).

Panov, V. E., Krylov, P. I. \& Telesh, I. V. 1999. The St. Petersburg harbour profile. In Initial Risk Assessment of Alien Species in Nordic Coastal Waters (Gollasch, S. \& Leppäkoski, E., eds.), pp. 225-244. Nordic Council of Ministers, Copenhagen.

Panov, V. E., Golubkov, S. M. \& Orlova, M. I. 2001. Littoral zone research in the Neva estuary (eastern Gulf of Finland): history and perspectives. Proc. Estonian Acad. Sci. Biol. Ecol., 50, 194-199.

Panov, V. E., Alimov, A. F., Golubkov, S. M., Orlova, M. I., Telesh, I. V., Balushkina, E. V. \& Anokhina, L. E. 2002. Environmental problems and challenges for coastal zone management in the Neva Estuary (eastern Gulf of Finland). In Baltic Coastal Ecosystems: Structure, Function and Coastal Zone Management (Schernewski, G. \& Schiewer, U., eds.), pp. 171184. CEEDES-Ser., Springer, Berlin.

Pitkänen, H., Kondratyev, S., Lääne, A., Gran, V., Kauppila, P., Loigu, E., Markovets, I., Pachel, K. \& Rumyantsev, V. 1997. Pollution load on the Gulf of Finland from Estonia, Finland and Russia in 1985-1995. Summary preport of Working Group Loading. In Proc. of the Final Seminar of the Gulf of Finland Year 1996 (Sarkkula, J., ed.), pp. 9-18. Suomen Ympäristökeskus, Helsinki.

Railkin, A. I. 1998. Processes of Colonization and Prevention from Fouling. St. Petersburg University (in Russian).

Schernewski, G. \& Schiewer, U. 2002. Status, problems and integrated management of Baltic coastal ecosystems. In Baltic Coastal Ecosystem: Structure, Function and Coastal Zone Management (Schernewski, G. \& Schiewer, U., eds.), pp. 1-16, CEEDES-Ser., Springer, Berlin. 
Shishkin, B. A., Nikulina, V. N., Maximov, A. A. \& Silina, N. I. 1989. The Main Characteristics of the Biota in the Top of the Gulf of Finland and Its Role in Water Quality Formation. Gidrometeoizdat, Leningrad (in Russian).

Strickland, J. D. H. \& Parsons, T. R. 1968. A practical handbook of seawater analysis. Fish. Res. Board Can. Bull., 167.

Suschenya, L. M. 1972. Respiration of Crustaceans. Naukova Dumka, Kiev (in Russian).

Wictor, J. 1969. Biologia Dreissena polymorpha (Pall.) i jei ecologiczne znaczenie w Zalewie Szczecinskim. Studi. Mater. Nor. Inst. Ryb. Gdynia. Ser A, 5, 1-88.

Winberg, G. G. 1983. Temperature coefficient of Vant Goff and Arenius's equation in biology. J. Gen. Biol., 44, 31-42.

Zmudzinski, L. 1996. The effect of introduction of the American species Marenzelleria viridis (Polychaeta: Spionidae) on the benthic ecosystem of Vistula Lagoon. Mar. Ecol., 17, 221226.

\title{
Eutrofeerumise ja rändkarbi (Dreissena polymorpha) sissetungi mõju Soome lahe idaosa rannikuvöötmes
}

\author{
Sergey M. Golubkov, Saara Bäck, Vera N. Nikulina, Marina I. Orlova, \\ Lydia E. Anokhina ja Ludmila P. Umnova
}

Ökosüsteemi uuringud Neeva suudmelahe litoraalis näitavad, et Soome lahe idaosa rannikuvöötme tõsine keskkonnaprobleem on eutrofeerumine, mis põhjustab niitvetika Cladophora glomerata vohamist ja perioodilist sinivetikate "õitsemist". Lainetus kisub Cladophora-vaipa põhjast lahti ja tekitab sellega Peterburi puhkealal teisest reostust. Põhjaloomastik, madalas litoraalis valdavalt ehmestiivaliste vastsed ja sügavamal võõrliik Dreissena polymorpha, soodustab niitvetikate kasvu, muutes vett selgemaks ja lastes toitaineid taas ringlusse. Keskkonnahoolduse oluline suund rannikuvöötmes on niitvetikate arengut soodustava kõva aluspõhja eemaldamine madalveest. 